International Journal of Computer Networks \& Communications (IJCNC) Vol.10, No.1, January 2018

\title{
On The Transmission OF ASYNCHRONOUS DATA Streams Over Packet Switched NeTWORKS With RANDOM MULTIPLE ACCESS
}

\author{
Yuriy Anatolievich Kropotov and Aleksander Anatolievich Kolpakov \\ Department of Electronics and Computer Science Vladimir State University named after \\ Alexander and Nicholay Stoletovs VlGU Murom, Russia
}

\begin{abstract}
The task of synchronizing discrete information on received data packets in packet-switched networks and random multiple access to the transmission medium is actual. In such channels, an asynchronous method of information transmission is provided. Therefore, in telecommunication systems, there is a problem of developing new methods for exchanging information and forming an effective structure for organizing clock synchronization for incoming data packets.
\end{abstract}

\section{KEYWORDS}

Synchronization process; packet communications; asynchronous data stream; discrete information; channels with a random multiple access

\section{INTRODUCTION}

The problem of formation of the synchronization of digital information in data packets received is relevant. This problem occurs when connecting to the packet data source information through the channel, which is the transmission rate is not known. For such channels are channels oriented asynchronous method of transmitting information, as well as channels with a random multiple access.

Being inherently asynchronous packet communication network (Frame Relay, ATM, IP) is primarily characterized by high-efficiency transmission of short messages. Unlike circuit-switched networks, resources which are provided for all connection time, packet communication network resources are assigned only for the transmitted information, even though the greatest effect is achieved in the absence of the essential requirements for its delivery time. However, the trend has led to the construction of the need to provide added functionality to transfer heterogeneous information integrated services networks. In ATM networks, for this reason, channels are provided with a constant bit rate channels with variable bit rate (real-time and non-real embodiments) channels available and non-guaranteed bit rate [1]. Similarly, Increasing the quality of service, and the possibility of being implemented in IP networks.

The communication network - a set of components(switches, routers and hubs), connected by a group of data transmission channels. In order to eliminate slippage and loss of bits or blocks of data packets over the network channels of information transfer must be carried out in ways agreed the time.

DOI: $10.5121 / \mathrm{ijcnc} .2018 .10108$ 
For this example, all the nodes are synchronized generators frequency one suitably selected, the master oscillator. In the absence of such synchronization, each node is equipped with its highprecision oscillator, providing a valid value of slippage or loss of items of data transmitted. communication quality depending on the said loss depends not only on the method of network synchronization, but also on a number of other factors [1] of the amplitude and phase distortion in the channels of fluctuation phase of signals from the code errors and timing errors, buffer overflow, the intensity of the applications and the transmission control protocol. The fractal nature of the processes in communication networks, finding, inter alia, reflected in the long tails of probability distributions of the number of applications, will also affect the quality of transmission and limits the ability of traditional, based on the queuing theory [2].

Also relevant are the issues of connecting devices to the ISDN subscriber-station via such digital channels with a random multiple access, as the development process of the formation of the clock signal from the clock station packet communication channel signal with a random multiple access requires further consideration and implementation of specific synchronization channels irrational. Therefore, in this paper, we consider the problem of forming the structure of the organization clocked by incoming data packets $[3,4]$.

\section{Channel Model Digital Data Transmission}

In accordance with the model channel digital data transmission shown in Fig. 1, the information $u(t)$ generated by the source is accumulated in the integrator and on reaching the threshold of comparator reset pulse to the channel element in the form of packets. packet repetition period is determined by the period of the accumulated information discretization pulse element. In general, the packet size may depend on the amount of accumulated information. However, without loss of generality assumed fixed packet size that matches the shape of the amplitude characteristic of the comparator, according to the channel model shown in Fig. 1.

Source data packet arrives at the buffer $\Sigma$ recipient with a delay $\tau$, which is a random variable $[5,6,7]$. Information from the specified buffer is sent forth to the recipient with the speed $v(t)$. This synchronization problem is to ensure the equality of conditions $v(t)=u\left(t-\tau_{0}\right)$, where $\tau 0$ fixed value.

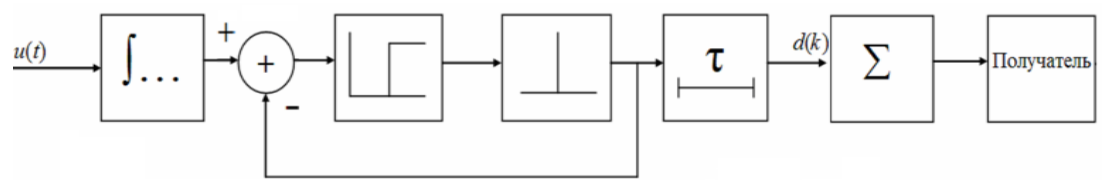

Fig 1. Block diagram of a channel model for the formation of data packets.

Seen from Fig. 1 that the source buffer is present integrator, the output of which is calculated difference between the amount of information accumulated in the integrator in unit time, the data accumulated pulse number information element and discharged into the channel in the form of packets. At the same time to eliminate the source of buffer overflows, the amount of information in the data packet D must be greater than the amount of information $W=\int_{0}^{\bar{T}} u(\vartheta) d \vartheta$ generated by a 
source in a time equal to the average of the sampling $\overline{\mathrm{T}}$ data accumulated pulse element. Thus, the condition $\mathrm{D}>\mathrm{W}$.

If speed packet data channel is significantly higher than the rate in the channel of the source, the output signal of the pulse element at the sampling point $t_{k}$, is a sequence of samples as a function

$$
\xi(t)=\frac{1}{2}(1+\operatorname{sgn}(x(t)-D)) \times D \times \delta\left(t-t_{k}\right)
$$

Where $x(t)$ function at the points $t_{k}$, where it can be discontinuous, continuous left adopted, sgn $a=1$, when $a \geq 0$ or $\operatorname{sgn} a=-1$, when a $<0$.

In accordance with (1) the amount of information dynamics of $x$ stored in the source buffer in the interval $\left[t_{k-1}, t_{k}\right]$ satisfies the difference equation

$$
\dot{x}_{k}(t)=u(t), x_{k}\left(t_{k}\right)=x_{k-1}\left(t_{k-1}\right)-\xi\left(t_{k-1}\right) .
$$

The integrated form of the equation (2) takes the form

$$
x_{k}(t)=x_{k-1}\left(t_{k-1}\right)+\int_{t_{k-1}}^{t_{k}} u(\vartheta) d \vartheta-\xi\left(t_{k-1}\right) .
$$

If we introduce the notation

$$
W_{k}=\int_{t_{k-1}}^{t_{k}} u(\vartheta) d \vartheta, x_{k}=x_{k}\left(t_{k}\right), u \xi_{k}=\xi\left(t_{k}\right),
$$

Then (3) the difference equation for the value of $x_{k}$, determining the source of the buffer filling in the moments $t_{k}$, as

$$
x_{k}=x_{k-1}+W_{k}-\xi_{k-1} .
$$

Greatly simplifies the solution of equation (4) when the conditions $W_{k}=W=$ const:

$$
x_{k}=x_{0}+k W-D\left[\frac{x_{0}+(k-1) W}{D}\right]
$$

Where $[b]$ - the integer part of the real number $b$.

The trajectories of the dynamical system described by equation (4), at $\mathrm{D}=48$ and fixed values $W_{k}=(0,2+\pi / 50) \cdot 48$ and $W_{k}=(0,8+\pi / 50) \cdot 48$ are shown in Fig. 2 and Fig. 3. 


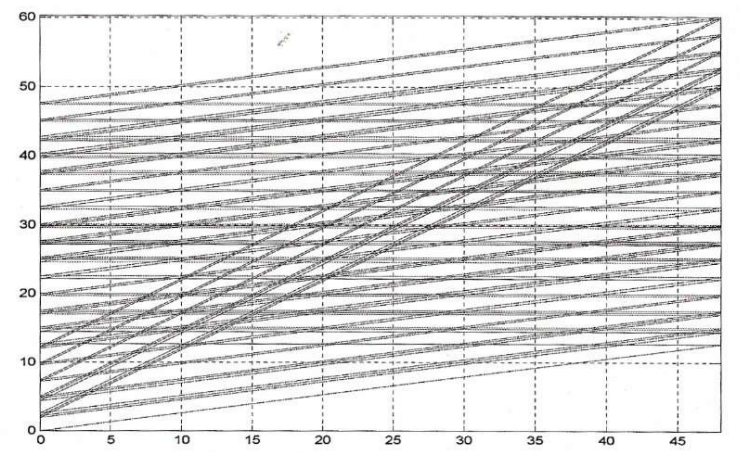

Fig 2. The dynamics of filling the buffer source: $\mathrm{Wk}=(0,2+\pi / 50) \bullet 48$.

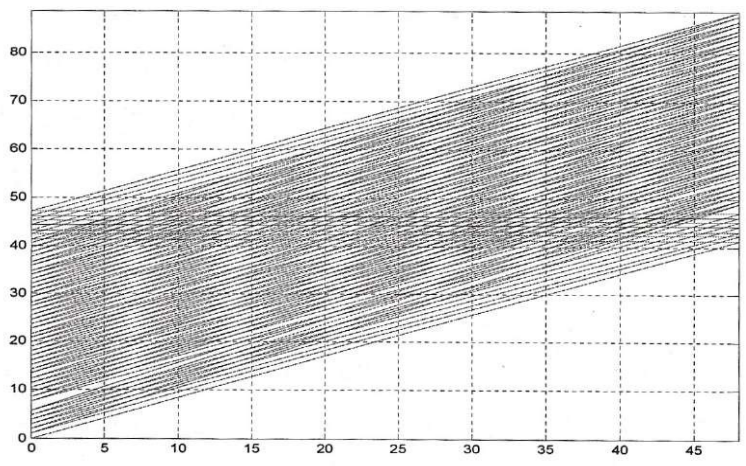

Fig 3. The dynamics of filling the buffer source: $\mathrm{Wk}=(0,8+\pi / 50) \bullet 48$.

Right boundary phase portraits are shown in Fig. 2 and Fig. 3 corresponds to the filling of the buffer at the time immediately preceding the point of sampling pulse element of the comparator output signal and the left border - fill the buffer after the sample to reset the data packet if the buffer filling at the time of sampling exceeds the volume of prisoners in the data packet. Movement on the phase portrait of the curve in the direction from the left edge to the right corresponds to a smooth change in the buffer is full, due to the accumulation of source data. Movement in the reverse direction at an angle to the horizontal correspond to abrupt changes caused by dumping of data packets.

From the figures it follows that the required buffer capacity decreases with an increase in the output of the comparator and the sampling frequency does not exceed a value equal to $2 \cdot \mathrm{D}$. However, the analysis model of the dynamics of the buffer filling shows that to ensure the reliability of the findings, the model should take into account uneven sampling of the accumulated data, and should take into account the changing generally random, delay in the delivery of data packets to the recipient. Sampling characteristics unevenness and shipping delays, in turn, determined by the peculiarities packet communication network protocols, the transmission speed of its channels, the nature of network access, network load and packet length distribution and priorities. In this case, the increase in the transmission channels and reducing network load reduces the sampling rate and delay variation unevenness at respective protocols, which in turn leads to the possibility of increasing the quality of communications in general. 
International Journal of Computer Networks \& Communications (IJCNC) Vol.10, No.1, January 2018

\section{Services Of Synchronous Traffic In Packet Communicat- Ion NETWORKS}

Group data channels connecting the respective pairs of packet communication network node can generally include information sources operating in different modes, such as synchronous and asynchronous modes (real-time and virtual). Naturally, all modes called group information channels comes in packet form. These sources operating in synchronous mode, while packed in packets with the expectation of their transmission network to a multicast channel. Driving group channel formation is shown in Fig. 4. The amounts of the active, synchronous and asynchronous, subscriber access junctions, which are functions of time, marked, respectively, as $n_{S}(t)$ and $n_{A}(t)$, the total number of joints $-n(t)=n_{S}(t)+n_{A}(t)$.

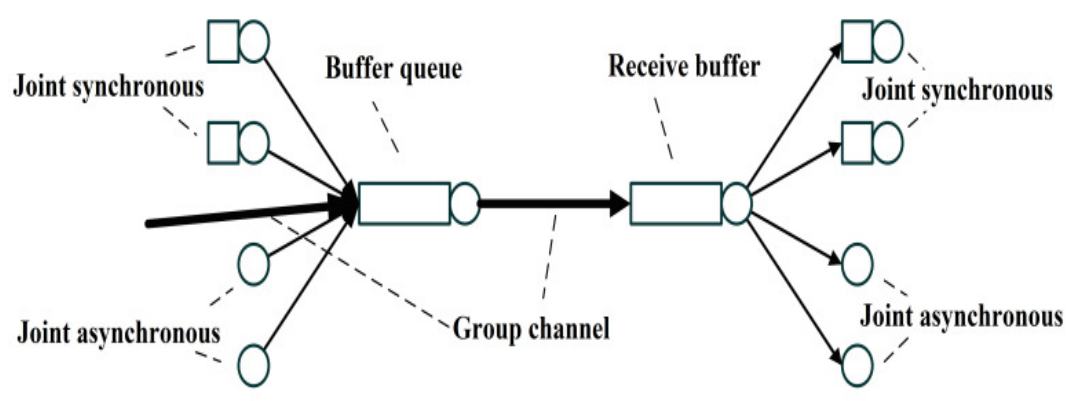

Fig 4. Group channel packet communication network.

Without limiting the generality of the packet length in the group channel in bits can be taken as a fixed value $\mathrm{d}_{\mathrm{P}}$, and the amount of information contained in it $-d_{I}$. Moreover, if the transmission rate is equal to the channel group $v_{P}$, while the maintenance of the package is given by $t_{P}=d_{P} / v_{P}$, and the effective data transmission rate contained in the package, - expression $v_{I}=d_{I} / t_{P}$.

Similarly, the time of one packet data channel in a synchronous $\mathrm{k}$ - th subscriber channel access $t_{S . k}=d_{I} / v_{S, k}$, where $v_{S, k}$ - the transmission rate in the channel. We can show that if time $t_{S . k}$ is not a multiple of the service time $t_{P}$, the stream of packets in the network is (with the irrational value of the ratio $\left.t_{S, k} / t_{P}\right)$ is almost periodic, and in general - random. Flow parameters also depend on the composition of the subscriber and network traffic junctions values in general, and their rules of service.

Thus, while the flow of data packets can be synchronous channels quite regular, the packet stream received by the asynchronous interface, naturally considered random. Formation synchronous packet channel is performed as shown in Fig. 4, buffers subscriber's joints. After each filling buffer interface packet arrives at the node corresponding buffer queue.

Moments packages entering the queue buffer $\tau_{1}$ form a point or a random thread (process) [8]. The parameters of this stream have a significant impact on the most important variables of network status - fill buffer queues of its nodes. Dynamics of changes in these variables taken a timing 
diagram similar to that shown in Fig. 5 diagram describing the operation of a network node - see Fig. 4, (or service unit). This is a typical method used in queuing theory [9].

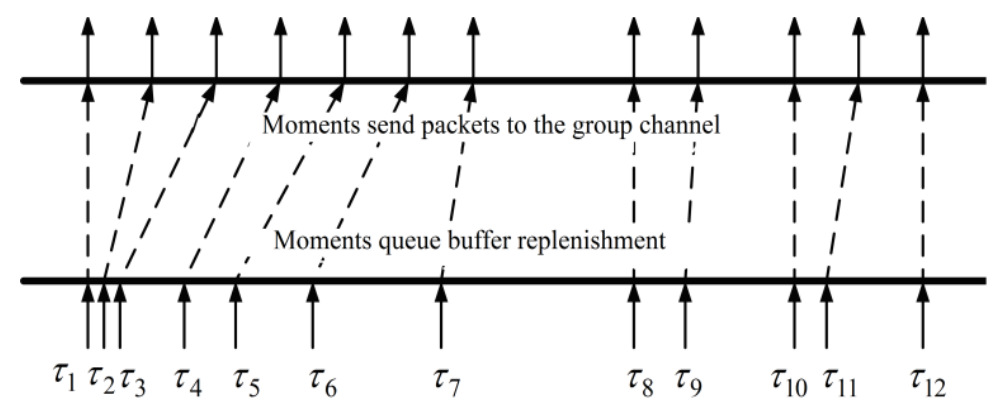

Fig 5. Timing diagram of service applications.

Fig. 5 shows an almost periodic order of receipt of applications for both synchronous and asynchronous interface, the total flow of orders and the order of service "first in - first out» (FIFO). Said service order, as is seen from the drawing, is characterized by irregular delivery of data packets to subscribers not only asynchronous but also synchronous interface, which, consequently, leads to a complication of the latter case synchronization problems. This problem is partly removed by fixing the synchronous channel for the packet data of predetermined positions, which, however, complicates the service control procedure.

The dynamics of filling the buffers is convenient to represent incomplete maintenance function [9]. Such a function can be constructed in accordance with the timing chart queuing - Fig. 5.The moment $\tau_{1}$ of receipt of the packet matches an abrupt increase in the filling stage buffer by the number of times the size of the package $d_{P}$. The intervals between the packet arrival moments buffer filling decreases with the data rate in the channel group $\mathrm{v}_{\mathrm{P}}$. Thus, each packet transmitted in the channel over time $t_{P}$.

A distinctive feature of queuing systems such as packet communication system (Fig. 4), is the nature of the input action, which is a random stream of short pulses within the $\delta$-function. In the simplest case, this can be a Poisson process, in which a random length $\theta$ of the interval between pulses $\tau_{1-1}$ and $\tau_{1}, 1=1,2,3, \ldots$ is described by the probability density function [10]

$$
f(\theta, l)=\lambda\left(\tau_{l-1}+\theta\right) e^{-\Lambda\left(\tau_{l-1}+\theta, \tau_{l-1}\right)}, \Lambda(t, a)=\int_{a}^{a+t} \lambda(\tau) d \tau .
$$

Here, $\lambda(t)-$ the flow rate (distribution parameter). In the case of a uniform flow when $\Lambda(t)=\lambda t$ the density distribution of the length of interval between pulses

$$
f(\theta)=\lambda e^{-\lambda \theta} .
$$

Uncompleted service feature that displays the dynamics of the group buffer channel line is the well-known sequence of moments of receipt of applications $\tau_{l}$, namely - described by the expressions 
$x_{l}(\rho)=\max \left\{0, x_{l-1}\left(\theta_{l-1}\right)+n_{l} d_{P}-v_{P} \rho\right\}, l=1,2,3, \ldots$,

$x_{l}\left(\theta_{l}\right)=\max \left\{0, x_{l-1}\left(\theta_{l-1}\right)+n_{l} d_{P}-v_{P} \theta_{l}\right\}, \theta_{1}=\tau_{1}-\tau_{1-1}, \rho \in\left[0, \theta_{l}\right]$.

Here, $x_{0}\left(\theta_{0}\right)$-the value of the initial filling of the buffer and $n_{1}$-the number of applicants at the time of $\tau_{1}$ application. The circuit model corresponding to equation (3) is shown in Fig. 6.

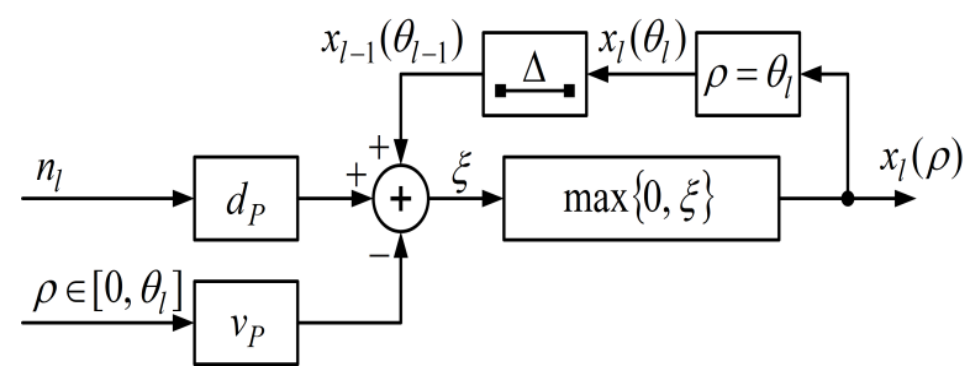

Fig 6. Shaper unfinished maintenance functions.

It follows from the above, the evaluation of the dynamics of the network buffers provided features of incomplete maintenance, still requires an adequate job of the total load and the time of receipt of applications. The total load must obviously be consistent with the channel capacity and packet arrival uneven - with the size of the buffers.

The dynamics of the filling channel of the group buffer, described by equation (3) is, strictly speaking, the only place with an infinite buffer size (in the absence of its overflow). At the end, the same amount of buffer $D_{P}$ filling dynamics can be represented by the equations

$$
\begin{aligned}
& x_{l}(\rho)=\max \left\{0, \min \left\{D_{P}, x_{l-1}\left(\theta_{l-1}\right)+n_{l} d_{P}\right\}-v_{P} \rho\right\}, l=1,2,3, \ldots, \\
& x_{l}\left(\theta_{l}\right)=\max \left\{0, \min \left\{D_{P}, x_{l-1}\left(\theta_{l-1}\right)+n_{l} d_{P}\right\}-v_{P} \theta_{l}\right\}, \\
& \theta_{l}=\tau_{l}-\tau_{l-1}, \rho \in\left[0, \theta_{l}\right] .
\end{aligned}
$$

Data loss due to buffer overflow described in this case the expression

$$
\Delta_{l}=\max \left\{0, x_{l-1}\left(\theta_{l-1}\right)+n_{l} d_{P}-D_{P}\right\}
$$

System model, which describes, in accordance with (4) and (5) the dynamics of filling the final size of the buffer and the resulting loss of data is an obvious generalization of the scheme shown in Fig. 6. 


\section{Restoration Of The Clock Frequency Of The Source}

One of the clock recovery problem by making the source data incoming packets may be based on a phase-locked loop shown in Fig. 7.

In this case, the available information that can be used when recovering the clock source frequency, registration points $\tilde{t}_{k}$ are received from the channel data and $\tilde{x}(t)$ packet receive buffer filling value.

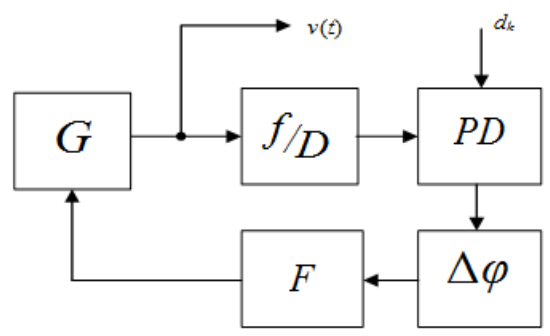

Fig 7. The phase locked loop circuit ( $\mathrm{G}$ - clock, f/D - the frequency divider function estimation average calculation repetition period of the data packets PD - a phase detector, ${ }^{\Delta \varphi}$ - forming the signal phase deviation, F - linear filter, a clock control signal generator frequency).

Depicted in Fig. 7 serves as a frequency divider estimation of the average repetition period $\bar{\theta}(t)$ of data packets. Designating the time of occurrence of pulses at the output of the divider as $\hat{t}_{k}$ the equation of the phase locked loop can be written as:

$$
v_{k}=v_{k-1}-\varepsilon\left(\tilde{t}_{k}-\hat{t}_{k}\right) \text {. }
$$

When using a linear feedback filter loop with finite impulse response [12] locked equation becomes:

$$
v_{k}=v_{k-1}-\varepsilon \sum_{k-N}^{k+M} a_{n}\left(\tilde{t}_{n}-\hat{t}_{n}\right),
$$

Which can be considered as a regulation equation averaged.

To account for the above equations in the automatic frequency unevenness forming the source sequence of data packets, application of adaptive control methods reference model $[13,15-22]$, which can be used as the above model of formation of the source data packets. In this case, instead of the frequency divider shown in Fig. 7, using a non-linear generator counts. To further control as the characteristic which can be used in the correction period, applies in this case, the deviation of the buffer to fill the recipient $\tilde{x}(t)$ of the buffer fill model $\overline{\bar{x}}(t)$. 
International Journal of Computer Networks \& Communications (IJCNC) Vol.10, No.1, January 2018

\section{CONCLUSION}

Thus, the design of discrete information transmission systems in accordance with the proposed structural model for the formation of data packets, the structure of the system model of the incomplete service function generator, the structural model for the phase-locked loop, constructed using adaptive control methods:

- allows to increase the speed of information transfer;

- reduces the effect of uneven sampling;

- reduces the effect of delay variation with the corresponding protocols;

- increases the dynamics of filling the buffer of a finite size and reduces data loss;

- improves the quality of the uneven generation of a sequence of source data packets, which results in improving the quality of packet communication in comparison with systems constructed by known methods of channel design.

Practical application of the issues addressed traffic synchronization in packet networks and the development of communication discussed the issue of forming the equation locked loop techniques of adaptive control is possible with the characteristics of the study and the protocol used by Packet communication channels within the framework of the present model. Also refer to the topic and issues developed in the theory of systems with random sampling period [4], and c variable delay [5], according to which the use of methods of stochastic systems requires information on the probability characteristics of the observed processes $[4,7,11,14]$.

\section{REFERENCES}

[1] Bellamy J. Cifrovaja telefonija [Digital telephony]. Moscow, Eco-Trendz, 2004. 640 p. (in Russian).

[2] Shelukhin O.I., Tenyakshev A.M, Osin A.V. Fraktal'nye processy v telekommunikacijah [Fractal processes in telecommunications]. Moscow, Radiotehnika, 2003. 480 p. (in Russian).

[3] Koltunov M.N., Ryzhkov A.V. Setevaja sinhronizacija: vzgljad v budushhee [Network synchronization: a look into the future]. Jelektrosvjaz', 2005, no. 9, pp. 36-38 (in Russian).

[4] Kazakov I.E., Artemyev V.A., Bukhalov V.A. Analiz sistem sluchajnoj struktury [Analysis of a random structure systems]. Moscow, Fizmatlit, 1993. 272 p. (in Russian).

[5] Solodov A.V., Solodova E.A. Sistemy s peremennym zapazdyvaniem [System with variable delay]. Moscow, Nauka, 1980. 384 p. (in Russian).

[6] Kropotov Y.A. Vremennoj interval opredelenija zakona raspredelenija verojatnosti amplitud rechevogo signala [The time interval determining the distribution law of probability amplitudes of speech]. Radiotehnika, 2006, no. 6, pp. 97-98 (in Russian).

[7] Ermolaev V.A., Kropotov Y.A. O korreljacionnom ocenivanii parametrov modelej akusticheskih jehosignalov [About correlation estimation of the parameters of acoustic echo models]. Voprosy radiojelektroniki, 2010, vol. 1, no. 1, pp. 46-50 (in Russian).

[8] Bolshakov I.A., Rakoshits V.S. Prikladnaja teorija sluchajnyh potokov [Applied theory of random streams]. Moscow, Sovetskoe radio, 1978. 248 p. (in Russian). 
International Journal of Computer Networks \& Communications (IJCNC) Vol.10, No.1, January 2018

[9] Kleinrock L. Teorija massovogo obsluzhivanija [Queueing theory]. Moscow, Mashinostroenie, 1979. 432 p. (in Russian).

[10] Solodov A.V., Solodov A.A. Statisticheskaja dinamika sistem s tochechnymi processami [Statistical dynamics of systems with point processes]. Moscow, Nauka, 1988. 256 p. (in Russian).

[11] Bykov A.A., KropotovY.A. Approksimacija zakona raspredelenija verojatnosti otschetov signalov akusticheskih pomeh [Approximation of law probability distribution of acoustic noise signal samples]. Radiotehnicheskie i telekommunikacionnye sistemy, 2011, no. 2, pp. $61-66$ (in Russian).

[12] Ermolaev V.A., Karasev O.E., Kropotov Y.A. Metod interpoljacionnoj fil'tracii v zadachah obrabotki rechevyh signalov vo vremennoj oblasti [Interpolation filtering method in problems of speech signal processing in the time domain]. Vestnik komp'juternyh i informacionnyh tehnologij, 2008, no. 7, pp. 12-17 (in Russian).

[13] Ermolaev V.A., Eremenko V.T., Karasev O.E., Kropotov Y.A. Identification of models for discrete linear systems with variable, slowly varying parameters. Journal of Communications Tehnology and Electronics, 2010, vol. 55, no. 1, pp. 52-57, New- York, USA.

[14] Kropotov Y.A. Algoritm opredelenija parametrov jeksponencial'noj approksimacii zakona raspredelenija verojatnosti amplitud rechevogo signala [The algorithm for determining the parameters of the exponential approximation law of the probability distribution of the amplitude of the speech signal]. Radiotehnika, 2007, no. 6, pp. 44-47 (in Russian).

[15] Kropotov Y.A., Ermolaev V.A. Algorithms for processing acoustic signals in telecommunication systems by local parametric methods of analysis. 2015 International Siberian Conference on Control and Communications (SIBCON-2015). Proceedings. Omsk: Omsk State Technical University. 2015. pp. 345-348. IEEE Catalog Number: CFP15794-CDR.

[16] Ermolaev V.A., Kropotov Y.A. Investigation of parameters of models of acoustic ECHO-signals by method of correlation estimation. Proceedings of 20 th International Crimean Conference "Microwave \& Telecommunication Technology". Sevastopol, Ukraine. 2010, vol.1, pp.422-423. IEEE Catalog Number CFP10788.

[17] Kropotov Y.A. Management of the channel suppression hindrances in multichannel systems of transfer acoustic signals. Proceedings of First Russia and Pacific Conference on Computer Technology and Applications (RPC 2010). Vladivostok: IACP FEB RAS, 2010, pp. 399-400.

[18] KropotovY.A. Statisticheskie parametry signalov pri proektirovanii operativno-komandnyh telekommunikacionnyh sistem [Statistical parameters of signals in the design of operational command of telecommunication systems]. V mire nauchnyh otkrytij, 2010, no. 6-1, pp. 39-44 (in Russian).

[19] Kropotov Y.A., Bykov A.A. Algoritm podavlenija akusticheskih shumov i sosredotochennyh pomeh s formantnym raspredeleniem polos rezhekcii [Algorithm acoustic noise suppression and interference with concentrated formant distribution rejection bands]. Voprosy radiojelektroniki, 2010, vol. 1, no. 1, pp. 60-65 (in Russian).

[20] Bykov A.A., Kropotov Y.A. Model' zakona raspredelenija verojatnosti amplitud signalov v bazise jeksponencial'nyh funkcij sistemy [Model law probability distribution of the signal amplitudes in the basis of the system of exponential functions]. Proektirovanie i tehnologija jelektronnyh sredstv, 2007, no. 2, pp. 30-34 (in Russian). 
International Journal of Computer Networks \& Communications (IJCNC) Vol.10, No.1, January 2018

[21] Belov A.A., Kropotov Y.A. Issledovanie voprosov szhatija i poiska kartograficheskoj informacii metodom vejvlet-preobrazovanij $\mathrm{v}$ jekologicheskoj geoinformacionnoj sisteme [Study on the compression and map information search method wavelet transforms environmental geographic information system]. Vestnik komp'juternyh i informacionnyh tehnologij, 2008, no. 12, pp. 9-14 (in Russian).

[22] Kropotov Y.A., Belov A.A. Issledovanie statisticheskih harakteristik ocifrovannyh signalov sistem telekommunikacij audioobmena [A study of the statistical characteristics of digitized signals telecommunications audioexchange]. Sistemy upravlenija, svjazi i bezopasnosti, 2015, no. 4, pp. 150157 (in Russian). 